\title{
СОЗДАНИЕ УЗКИХ КОРРЕКЦИОННЫХ МЕТОДИК РЕАБИЛИТАЦИИ ДЛЯ ДЕТЕЙ С ДЕТСКИМ ЦЕРЕБРАЛЬНЫМ ПАРАЛИЧЕМ
}

Копылов Тимофей Александрович студент

Институт реабилитации и здоровья человека Национальный исследовательский Нижегородский государственный университет им. Н.И. Лобачевского

Кирьянова Ксения Андреевна магистр

Национальный государственный университет физической культуры, спорта и здоровья имени П. Ф. Лесгафта

Аннотация. Разработана специальная методика упражнений, которые могут применяться в рамках коррекционно-педагогической работы с детьми, имеющими различные нарушения опорно-двигательного аппарата. Наибольшую эффективность данный метод может показать при реабилитации детей с детским церебральным параличом 4 степени (по GMFCS).

Ключевые слова: детский церебральный паралич, реабилитация, методы, коррекционно-педагогическая работа.

\section{CREATION OF FOCUSED CORRECTIONAL REHABILITATION METHODS FOR CHILDREN WITH CEREBRAL PALSY}

\section{Kopylov Timofey Alexandrovich Kiryanova Ksenia Andreevna}

\begin{abstract}
We has been developed a special method of exercises that can be used as part of correctional and pedagogical work with children with various disorders of the musculoskeletal system. This method can show the greatest efficiency in the rehabilitation of children with cerebral palsy of the 4th degree (according to GMFCS).

Key words: cerebral palsy, rehabilitation, methods, correctional and pedagogical work.
\end{abstract}


Введение. В конце 20-го начале 21 века отмечается тенденция к росту врожденных и приобретенных нарушений функционирования опорнодвигательного аппарата (ОДА) у детей. Особое место среди этих заболеваний занимает детский церебральный паралич (ДЦП) [1, с. 205]. Коррекционнопедагогическая работа с детьми, страдающими ДЦП включает в себя приемы психотерапии, социальной адаптации, физиотерапии, медикаментозного лечения в зависимости от категории и вида ДЦП [2, с. 72]. Однако, на первое место встает поиск индивидуального подхода к ребенку с целью восстановления, в первую очередь, двигательных навыков. Для этого в комплекс коррекционной работы необходимо включать лечебную физическую культуру (ЛФК) и лечебную гимнастику.

Современная модель коррекционно-педагогической работы предполагает обязательную оценку степени нарушения двигательных функций ребенка по шкале глобальных двигательных функций GMFCS (Gross Motor Function Classification System). Однако, достаточно широко представленные в литературе методы физической реабилитации носят общий характер и не учитывают индивидуальных особенностей больных детей. Современная медицина и коррекционная педагогика стремятся с учетом возраста, оценки состояния, уровня по классификации GMFCS и реабилитационного потенциала ребенка создать гибкие методики восстановления нарушенных функций опорно-двигательного аппарата, которые позволили бы найти индивидуальный подход к маленькому пациенту [1, с. 207].

Исходя из выше изложенного, целью явилась разработка индивидуальной методики реабилитации детей с детским церебральным параличом 4 степени в рамках общей коррекционно-педагогической деятельности.

В данной работе представлены методы, охватывающие лишь часть процессов, происходящих в ходе коррекционной работы, а именно восстановление двигательных навыков.

Результаты исследования и их обсуждение. Известно, что дети с ДЦП 4 степени (по GMFCS) не могут самостоятельно передвигаться, склонны к болям, а также имеют высокий риск развития ортопедических осложнений. Они рано достигают плато в развитии моторики и очень быстро теряют функции опорнодвигательного аппарата, а значит социальные и бытовые навыки [4, с. 149].

Поэтому, в первую очередь, целью реабилитации таких детей является коррекция осанки. Коррекция некоторых базовых положений с целью достижения их правильного анатомо-физиологического вида способствует 
профилактике контрактур, что имеет решающее значение в реабилитации больных детским церебральным параличом [5, с. 306]. Также сохраняется возможность пассивной вертикализации реабилитируемого, минимизация операций и устранение лишних движений.

Для этого нами разработан метод круговой тренировки с постановкой и удержанием занимающегося в определенных статических и динамических положениях.

Локация для занятий разделена на несколько станций, на каждой станции тренер-реабилитолог ставит ребенка в определенные позы, а после установки его в исходное положение начинает с ним делать повторения или удержания движений.

Удерживающее упражнение. Постановка ребенка в исходное положение на четвереньки с опорой на прямые руки. Далее тренер номер один поднимает руку ребенка и держит ее параллельно полу, тренер номер два поднимает противоположную ногу до положения, параллельного полу. Далее тренеры меняют руку и ногу на противоположные. Упражнение выполняется в несколько повторений в зависимости от физической подготовленности ребенка.

Упражнение на повторение. Исходное положение на боку. Тренажер помогает ребенку заниматься упражнением отведения и приведения ноги в тазобедренном суставе.

Для детей с ДЦП 4 степени (по GMFCS) возможно только пассивное выполнение двигательных действий. Разработанный нами вид тренировки с удержанием различных положений, а также выполнением упражнений на повторение может способствовать предупреждению потери тонуса в различных группах мышц, устранению или ослаблению спастичности (например, при спастическом церебральном параличе, являющемся наиболее распространенной формой детский церебральный паралич). Также такие тренировки могут способствовать развитию статического равновесия, нарушение которого очень часто встречается при различных формах детского церебрального паралича. Тренеру-педагогу следует уделять особое внимание контролю и формированию позиции занимающегося для предотвращения деформации позвоночного столба.

Разработанная нами методика способствует снижению дегенеративных процессов в мышечной ткани. Так же данные методы, по нашему мнению, формируют двигательные навыки соответствующие возрасту ребенка; активизируют мышечную память, что позволит выполнять данные упражнения самостоятельно без поддержки тренера-педагога. 
Вывод. Таким образом, нами разработаны упражнения, соответствующие целям коррекционной работы детей с ДЦП 4 степени, а также основным принципам реабилитации. Данная методика очень гибкая и позволяет работать с людьми с различными нарушениями опорно-двигательного аппарата, однако мы рекомендуем использовать ее, в основном, для детей с ДЦП 4 степени по GMFCS. Надеемся, что эту методику внедрят в свою работу специалисты в области и коррекционной педагогики, и реабилитации.

\section{Список литературы}

1. Рахмаева Р.Ф., Камалова А.А., Аюпова В.А. Оценка антропометрических показателей и компонентного состава тела у детей с детским церебральным параличом // Российский вестник перинатологии и педиатрии. - 2019. - Т. 64. - №5. - С. 204-208.

2. Галиева Г.Ю., Панченко Т.Н., Валуева И.В. и др. Современные подходы и методы физической терапии в реабилитации детей с ДЦП в условиях клинического психоневрологического санатория // Медицина в Кузбассе. 2018. - №4. - С. 72-75.

3. Белова А.Н., Шейко Г.Е., Шаклунова Н.В. и др. Медицинская реабилитация при детском церебральном параличе: применение международной классификации функционирования, ограничений жизнедеятельности и здоровья детей и подростков // Вестник восстановительной медицины. - 2019. - №1 (89). - С. $2-9$.

4. Карякин Н.Н., Шейко Г.Е., Воловик М.Г. и др. Технологии виртуальной реальности в комплексной медицинской реабилитации пациентов с детским церебральным параличом // Бюллетень сибирской медицины. 2020. - T.19. — № 2. - С. 142-152.

5. Семёнова Е.В., Клочкова Е.В., Коршикова-Морозова А.Е. и др. Реабилитация детей с ДЦП: обзор современных подходов в помощь реабилитационным центрам. - Москва: Лепта Книга. - 2018. - 584 с.

(C) Т.А. Копылов, К.А. Кирьянова, 2022 